\title{
Chlamydia trachomatis and ectopic pregnancy: retrospective analysis of salpingectomy specimens, endometrial biopsies, and cervical
} smears

\author{
J Lan, A J C van den Brule, D J Hemrika, E K J Risse, J M M Walboomers, \\ M E I Schipper, C J L M Meijer
}

\begin{abstract}
Aims-To examine the role of Chlamydia trachomatis in ectopic pregnancy by detection of DNA in archival salpingectomy specimens, and in their preceding cervical specimens and endometrial biopsies, by using the polymerase chain reaction (PCR).

Methods-Archival paraffin embedded salpingectomy tissues $(n=48)$ from 37 women with ectopic pregnancy were examined for the presence of $\boldsymbol{C}$ trachomatis plasmid and omp1 DNA by PCR. In addition, preceding cervical specimens $(n=$ 58) stored either as cervical cell suspensions or as archival cervical smears, and preceding endometrial biopsies $(n=$ 18), taken $0-5.8$ years before the ectopic pregnancy, were examined by PCR for the presence of $\mathrm{C}$ trachomatis.
\end{abstract}

Results-C trachomatis DNA was detected in only one of the 48 salpingectomy specimens from 37 women. However, in six of the 37 women, $C$ trachomatis DNA was detected in the genital specimens (cervix and/or endometrial) taken before salpingectomy. C trachomatis infections were mostly found in endometrial or cervical specimens taken more than three years before ectopic pregnancy. No chlamydial DNA was found in endometrial or cervical specimens taken at the same time of the ectopic pregnancy.

Conclusions-Although no $\boldsymbol{C}$ trachomatis DNA was found in salpingectomy specimens, several women with ectopic pregnancy had $C$ trachomatis infections in endometrial and cervical specimens in the past. This suggests that at least in these cases the ectopic pregnancy is a late postinflammatory complication of an ascending $\boldsymbol{C}$ trachomatis infection resulting in a scarred fallopian tube.

(f Clin Pathol 1995;48:815-819)

Keywords: Chlamydia trachomatis, polymerase chain reaction, ectopic pregnancy.

The incidence of ectopic pregnancy has increased in many industrialised countries during the last two decades. ${ }^{1-5}$ About $98 \%$ of ectopic pregnancies are tubal, often as a result of tubal damage after one or more episodes of pelvic inflammatory disease. ${ }^{6}$ The increasing in- cidence of ectopic pregnancy has led to many investigations of its microbial aetiology. Chlamydia trachomatis, one of the most common bacterial pathogens of sexually transmitted diseases, has been reported to be associated with ectopic pregnancy, ${ }^{7-9}$ as shown by the significantly increased incidence (twoto sevenfold) of antichlamydial IgG antibodies in sera from patients as compared with controls. $^{7-15}$ Moreover, studies of the microbial aetiology of pelvic inflammatory disease have shown that $C$ trachomatis was present in the fallopian tubes at the time of salpingitis. ${ }^{16-19}$ So far the mechanism by which $C$ trachomatis induces tubal damage in ectopic pregnancy remains unclear. It is speculated that persistent $C$ trachomatis infection may cause tubal damage directly, or the occlusion may otherwise be the indirect result of post inflammatory damage. However, isolation of $C$ trachomatis by cell culture from the resected salpinx of ectopic pregnancies has not been successful to date. ${ }^{1320-22}$ Since the existence of a non-cultivable form of $C$ trachomatis has been suggested, ${ }^{23-25}$ the role of this microorganism at the time of the ectopic pregnancy is still unclear.

DNA detection by polymerase chain reaction (PCR) has been successfully applied to paraffin embedded tissues and archival cervical smears. $^{2627}$ This offers the possibility of detecting $C$ trachomatis independently of its viability, and also allows retrospective studies to be carried out using archival materials. Therefore we looked for the presence of $C$ trachomatis by PCR in archival salpingectomy specimens of women with ectopic pregnancy. To study a possible association between a previous period of ascending $C$ trachomatis infection and the later occurrence of ectopic pregnancy, available preceding cervical specimens and endometrial biopsies from the corresponding cases were also examined for the presence of $C$ trachomatis DNA by PCR.

\section{Methods}

MATERIALS

Forty eight archival paraffin embedded salpingectomy tissues from 37 women with ectopic pregnancy (mean age 33 years) were collected at the Free University hospital and the OLVG hospital, Amsterdam. Two paraffin blocks were tested from 11 of the 37 women. In eight of these women two blocks from the 
Table 1 Summary of the 37 cases tested for $\mathrm{C}$ trachomatis (CT) DNA in salpingectomy specimens ( $\square / \square)$, and in preceding endometrial $(\Delta / \triangle)$ and cervical specimens $(O / O)$ in relation to the time intervals (years) between the sampling

\begin{tabular}{|c|c|c|c|c|c|c|}
\hline \multirow[b]{2}{*}{ Case No. } & \multicolumn{6}{|c|}{ Time intervals (years) before salpingectomy } \\
\hline & 0 & $<1$ & $1-2$ & $2-3$ & $3-4$ & $>4$ \\
\hline $\begin{array}{r}1 \\
2 \\
3 \\
4 \\
5 \\
6 \\
7 \\
8 \\
9 \\
10 \\
11 \\
12 \\
13 \\
14 \\
15 \\
16 \\
17 \\
18 \\
19 \\
20 \\
21 \\
22 \\
23 \\
24 \\
25 \\
26 \\
27 \\
28 \\
29 \\
30 \\
31 \\
32 \\
33 \\
34 \\
35 \\
36 \\
37\end{array}$ & $\begin{array}{l}a^{*} \\
\square \\
\square \\
\square^{*} \\
\square^{*} \\
\square^{*} \\
\square \\
\square^{*} \\
\square^{* *} \\
\square^{* *}(2 \mathrm{x}) \\
\square^{* *}(2 \mathrm{x}) \\
\square \\
\square(2 \mathrm{x}) \\
\square(2 \mathrm{x}), 0 \\
\square, 0 \\
\square \\
\square, 0 \\
\square \\
\square^{* *}(2 \mathrm{x}) \\
\square^{*}(2 \mathrm{x}), 0 \\
\square \\
\square \\
\square \\
\square, \triangle \\
\square \\
\square^{*} \\
\square^{*} \\
\square * \\
\square \\
\square^{*} \\
\square * \\
\square \\
\square \\
\square^{*}(2 \mathrm{x}), 0 \\
\square \text { (2x) }\end{array}$ & $\begin{array}{l}O(2 x) \\
0 \\
0 \\
0 \\
\bigcirc \\
\triangle\end{array}$ & $\begin{array}{l}\triangle \\
\triangle \\
\bigcirc \\
\bigcirc \\
\square^{\mathrm{b}}, \triangle \\
\bigcirc(2 \mathbf{x}), \triangle(2 \mathbf{x})\end{array}$ & $\begin{array}{l}0 \\
\triangle, 0 \\
0 \\
0 \\
\bigcirc \\
\bigcirc, \triangle\end{array}$ & $\begin{array}{l}\bigcirc \\
\Delta, 0 \\
\bigcirc(2 x) \\
\bigcirc \\
\bigcirc, \triangle \\
\bigcirc \\
\bigcirc\end{array}$ & $\begin{array}{l}\boldsymbol{\Delta} \\
\boldsymbol{\Delta} \\
\mathrm{O}\end{array}$ \\
\hline
\end{tabular}

a The cases are presented in order of CT positive $(\square, \Delta, O)$ and CT negative $(\square, \triangle, O)$ as determined by plasmid PCR. b Tubal biopsies.

* Tubal tissues with presence of plical conglutination and fibrosis.

** Tubal tissues with presence of fibrosis.

same salpingectomy were available, and the other three had tubal biopsies taken earlier before the salpingectomy. Case selection was based on the availability of preceding genital specimens - that is, cervical specimens or endometrial biopsies, or both-taken at different times before the ectopic pregnancy (see table 1) in patients from whom salpingectomy specimens were available in the archive. The genital specimens included stored cervical cell suspensions $(n=19)$, archival cervical smears $(n=$ 39) used previously for Papanicolaou (PAP) classification, and endometrial biopsies $(\mathrm{n}=$ 18). The cervical smears were taken as part of a routine screening programme for cervical neoplasia, and the endometrial biopsies were taken routinely during infertility investigation. The time intervals between the sampling of different specimens are listed in table 1 .

\section{SAMPLE PREPARATION}

The samples were processed for PCR as follows. Paraffin embedded tissues (salpingectomy tissues and endometrial biopsies) were serially cut in $4 \mu \mathrm{m}$ sections. Plain paraffin blocks were included between tissue blocks to check for cross contamination between the tissues during sectioning. The first and the last sections were stained with haematoxylin and eosin for histological re-examination, whereas the sections in between were used for PCR. Proportionally, $1 \mathrm{~cm}^{2}$ of the $4 \mu \mathrm{m}$ tissue section was directly digested in a $250 \mu$ proteinase $\mathrm{K}$ buffer ${ }^{28}$ containing $500 \mathrm{pg} / \mathrm{ml}$ proteinase $\mathrm{K}$, $0.45 \%$ Tween $20,0.45 \%$ Nonidet P-40, $31.25 \mu \mathrm{l}$ of the PCR buffer $(10 \times: 15 \mathrm{mM}$ $\mathrm{MgCl}_{2}, 100 \mathrm{mM}$ Tris-HCI (pH 8.3), and $500 \mathrm{mM} \mathrm{KCl}$ ), at $37^{\circ} \mathrm{C}$ for $24 \mathrm{~h}$. The proteinase $\mathrm{K}$ was inactivated by boiling and a $40 \mu \mathrm{l}$ portion of supernatant was subjected directly to PCR amplification. The inserted plain paraffin sections were simultaneously processed for PCR. In cases of unsatisfactory tissue processing by this direct proteinase $\mathrm{K}$ digestion (as indicated by an unsuccessful human $\beta$ globin amplification, see below), DNA was purified from these paraffin sections as follows: four or five sections were deparaffinised with xylene, washed twice in ethanol, and air dried. The dry pellets were digested in the proteinase $\mathrm{K}$ buffer described above for $2 \mathrm{~h}$ at $42^{\circ} \mathrm{C}$ on a shaker, and the supernatants were extracted twice with phenol/chloroform/isoproponol (vol/ vol/vol: 24:25:1) and precipitated by ethanol. The purified DNA was resuspended in $10 \mathrm{mM}$ Tris-HCI (pH 7.5). Approximately $100 \mathrm{ng}$ DNA were used for PCR.

Cervical scrapes-These were collected with cervix brushes (Rover BV) in phosphate buffered saline. Samples were centrifuged for $10 \mathrm{~min}$ at $4000 \mathrm{~g}$, and the pellets were resuspended in $1 \mathrm{ml}$ Tris- $\mathrm{HCl}(0.01 \mathrm{M}, \mathrm{pH} \mathrm{7.5)}$ and stored at $-80^{\circ} \mathrm{C}$ until use. Subsequently $10 \mu \mathrm{l}$ of this freeze thawed sample was used for PCR amplification.

Archival cell smears-Cells were scraped off the smears and DNA was isolated as described 
Table 2 List of primers used for human $\beta$ globin PCR and chlamydial PCRs

\begin{tabular}{|c|c|c|c|}
\hline Primers and probes & Reference & Nucleotide sequences & $\begin{array}{l}\text { Length of amplimer } \\
(b p)\end{array}$ \\
\hline $\begin{array}{l}\text { Human } \beta \text { globin PCR } \\
\text { BGPCO3-1 (sense primer) } \\
\text { BGPCO5 (antisense primer) } \\
\text { BGPCO6 (antisense primer) }\end{array}$ & $\begin{array}{l}36 \\
* \\
*\end{array}$ & $\begin{array}{l}\text { 5'-ACACAACTGTGTTCACTAGC-3' } \\
\text { 5'-GAAACCCAAGAGTCTTCTCT-3' } \\
\text { 5'-CATCAGGAGTGGACAGATCC-3' }\end{array}$ & $\begin{array}{l}209 \\
326\end{array}$ \\
\hline $\begin{array}{l}\text { C trachomatis plasmid PCR } \\
\text { CTP1 (sense primer) } \\
\text { CTP2 (antisense primer) } \\
\text { PCTP5 (probe) }\end{array}$ & 31,32 & $\begin{array}{l}\text { 5'-TAGTAACTGCCACTTCATCA-3' } \\
\text { 5'-TTCCCCTTGTAATTCGTTGC-3' } \\
\text { 5'-ATCTCATTACCATGCATTAGCAGCTATCCA-3' }\end{array}$ & 201 \\
\hline $\begin{array}{l}C \text { trachomatis omp1 PCR } \\
\text { CM2A (sense primer) } \\
\text { CM3A (antisense primer) }\end{array}$ & 34 & $\begin{array}{l}\text { 5'CCAAGCCTTATGATCGACGG-3' } \\
\text { 5'-GAATACATCAAAACGATCCC-3' }\end{array}$ & 320 \\
\hline
\end{tabular}

* Primers were selected by computer analysis with PC/gene software (release 6.7, EMBL35, uGenbank 77-35, IntelliGenetics Inc, Mountain View CA, USA).

previously. ${ }^{29} 30$ Briefly, the cover slip was removed by xylene in a sterile container and the cells were scraped off separately with sterile blades. Cells were washed once with xylene and twice with ethanol. The pellets were air dried and lysed in the lysate buffer containing $50 \mathrm{mM}$ Tris- $\mathrm{HCl}$ (pH 6.4), $20 \mathrm{mM}$ EDTA, $1.3 \% \mathrm{wt} / \mathrm{vol}$ Triton-X 100 , and $5 \cdot 25 \mathrm{M}$ guanidinium thiocynate for $2 \mathrm{~h}$ at room temperature. DNA released in the lysate was bound to activated silica $(50 \mu \mathrm{l}$ Silica, Fluka, $1 \mathrm{~g} / \mathrm{ml}$ suspension in $0 \cdot 1 \mathrm{~N} \mathrm{HCl}$ ). After washing twice with wash buffer ( $50 \mathrm{mM}$ Tris- $\mathrm{HCl}, \mathrm{pH} 6.4$, plus $5 \cdot 25 \mathrm{M}$ guanidinium thiocynate) and once with $70 \%$ ethanol, the pellets were air dried and the DNA was recovered in $200 \mu$ l Tris$\mathrm{HCI}(\mathrm{pH} 8.3)$ at $58^{\circ} \mathrm{C}$. Ten microlitres were used for PCR.

POLYMERASE CHAIN REACTION

Each specimen was subjected to human $\beta$ globin PCR to check for the suitability of the processed sample for PCR purposes. Two different $\beta$ globin PCRs were used, amplifying either $209 \mathrm{bp}$ or $326 \mathrm{bp}$ DNA fragments equivalent to the fragment lengths generated by the chlamydial plasmid $P C^{31-33}$ and $o m p 1$ PCR,${ }^{34}$ respectively. The $o m p 1$ PCR was performed in order to detect a possible plasmidfree $C$ trachomatis strain which is so far described as a laboratory strain. ${ }^{35}$ The primer sequences and the fragment lengths of generated PCR products are listed in table 2 . PCR was performed in a final volume of $50 \mu \mathrm{l}$ containing of $50 \mathrm{mM} \mathrm{KCl}, 10 \mathrm{mM}$ Tris- $\mathrm{HCl}$ (pH 8.3), $200 \mu \mathrm{M}$ of each deoxynucleotide (dATP, dTTP, dGTP, and dCTP), $1.5 \mathrm{mM}$ $\mathrm{MgCl}_{2}, 1 \mathrm{U}$ of Taq DNA polymerase (Amplitaq, Perkin Elmer), and either 25 pmol of each $\beta$ globin primer or $50 \mathrm{pmol}$ for each chlamydial primer. The PCR amplification consisted of a DNA denaturation at $95^{\circ} \mathrm{C}$ for $4 \mathrm{~min}$ followed by 40 cycles of amplification which were performed with a thermocycler (Biomed). Each cycle consisted of denaturation at $95^{\circ} \mathrm{C}$ for $1 \mathrm{~min}$, annealing at $55^{\circ} \mathrm{C}$ for 1 $\mathrm{min}$, and chain elongation at $72^{\circ} \mathrm{C}$ for $1.5 \mathrm{~min}$. The final elongation was extended for another $4 \mathrm{~min}$. Human placental DNA (100 ng) was used as a positive control for $\beta$ globin PCR. Dilution series of $C$ trachomatis serovar L2 DNA, corresponding to $0 \cdot 01,0 \cdot 1$, and 1 inclusion forming units, were used as positive controls for chlamydial PCRs. An additional positive control using a paraffin embedded salpingectomy tissue derived from a patient with $C$ trachomatis salpingitis was used for PCR performed with paraffin embedded tissues. An additional $C$ trachomatis positive cervical smear was used for PCR performed with cervical smears. Distilled water instead of DNA was used as negative control. Finally, $10 \mu \mathrm{l}$ of the PCR products were analysed by $1.5 \%$ agarose gel electrophoresis. $C$ trachomatis plasmid PCR products were further analysed by Southern blot hybridisation using an internal oligonucleotide (table 1) end labelled with $\left[\mathrm{r}^{32} \mathrm{P}\right]-$ ATP. ${ }^{31}$ Chlamydial $o m p 1$ PCR products were hybridised with a cocktail probe consisting of random primer labelled with $\left[\alpha-{ }^{32} \mathrm{P}\right]-\mathrm{dCTP}$ omp1 PCR products derived from $15 C$ trachomatis reference strains for detection of $C$ trachomatis. $^{32}$

\section{Results}

In the 48 salpingectomy specimens (from 37 women) which we examined, $\beta$ globin PCR generated a $209 \mathrm{bp}$ fragment in 45 samples processed by direct proteinase $\mathrm{K}$ digestion, while after DNA extraction the three remaining samples also became positive. $C$ trachomatis DNA was found by plasmid PCR in only one of these $\beta$ globin PCR positive tubal tissues (table 1). The $\beta$ globin PCR generating a $326 \mathrm{bp}$ was successful in 33 of the 48 tissues examined. However, in these $\beta$ globin positive $(326 \mathrm{bp}$ ) samples no additional samples were found to be positive by the omp 1 PCR, amplifying a $320 \mathrm{bp}$ fragment. Positive controls for chlamydial PCRs using a dilution series of $C$ trachomatis serovar L2 DNA had a sensitivity corresponding to 0.01 inclusion forming units after Southern blot hybridisation in both chlamydial PCRs. The positive control, using $C$ trachomatis positive salpingectomy tissue, was positive in both PCRs. In addition, plain paraffin sections cut between two cases and processed for PCR simultaneously remained negative.

All cervical specimens (cell suspensions and smears) were positive by $\beta$ globin PCR generating a $209 \mathrm{bp}$ fragment. Six of the 58 cervical specimens, derived from five women, were found to contain $C$ trachomatis DNA by plasmid PCR (table 1). In addition, 15 of the 19 cervical cell suspension and 35 of the 39 smears were 
positive by 326 bp $\beta$ globin PCR. However, no additional positive samples were found by $o m p 1$ PCR (320 bp). The positive control using a $C$ trachomatis positive cervical smear was found to be positive in all chlamydial PCRs performed with cervical smears.

All 18 endometrial biopsies examined were suitable for PCR amplification of a $\beta$ globulin fragment of $209 \mathrm{bp}$ using either direct proteinase $K$ digestion $(n=13)$ or DNA extraction $(\mathrm{n}=5)$. $C$ trachomatis DNA was found by plasmid PCR in three biopsies from three different women (table 1). In addition, 13 of the 18 biopsies were positive for $326 \mathrm{bp} \beta$ globin PCR, but no additional positive samples were found by omp1 PCR (320 bp).

Table 1 summarises the results of 37 ectopic pregnancy cases in which the presence of $C$ trachomatis DNA was sought by PCR in the salpingectomy tissues, the endometrial biopsies, or the cervical specimens in relation to the time intervals between the sampling.

The histological picture of the salpingectomy specimens was that of a mild round cell infiltrate consisting of lymphocytes and some plasma cells. In two of these cases there was admixture with eosinophilic granulocytes. In 19 of the tubal specimens, plical conglutination or fibrosis was present (table 2). The specimen that was positive for $C$ trachomatis also showed plical conglutination, fibrosis, and some lymphocyte and plasma cell infiltration (table 2, case 1). All cervical smears showed PAP I or II cytomorphology. No endometrial specimens showed any sign of inflammation.

\section{Discussion}

In this study we found that the PCR can be successfully applied for the detection of $C$ trachomatis DNA in paraffin embedded tissues and archival cervical smears, indicating that this technique could be very useful for the retrospective analysis of the role of $C$ trachomatis in late complications such as ectopic pregnancy. Because of damage to the DNA templates as a result of fixation or storage, the fragment length in PCR amplification is restricted. In this study, fragments of up to $326 \mathrm{bp}$ could be efficiently amplified in the majority of the specimens. The incorporation of the $\beta$ globin PCR was therefore important for a reliable interpretation of the chlamydial PCR data.

As shown in this study, $C$ trachomatis DNA was not, or only sporadically (1/48), present in salpingectomy tissues at the time of ectopic pregnancy. These PCR results rule out the possibility of infection with a non-cultivable form of $C$ trachomatis, as has been suggested by others, ${ }^{23-25}$ and are in agreement with those studies reporting that direct isolation of $C$ trachomatis by cell culture from the salpingectomy specimens of ectopic pregnancies was not successful. ${ }^{1320-22}$ In addition, infections with plasmid-free $C$ trachomatis strains, so far only described as a laboratory strain, ${ }^{35}$ can also be ruled out, since no additional positivity was found by omp 1 PCR. The sporadic incidence of $C$ trachomatis infection found in tubal tissues of ectopic pregnancy and the high seropositivity found by others ${ }^{7-15}$ probably reflects episodes of $C$ trachomatis infection in the past. Indeed, $C$ trachomatis DNA was found in preceding genital specimens (cervical specimens or endometrial biopsies) in six of the 37 women with ectopic pregnancy (table 1). Although the numbers of $C$ trachomatis positive specimens are small, the increasing incidence of $C$ trachomatis infection is reflected in the increasing time span before ectopic pregnancy: in $31 \%$ of women (five of 16) $C$ trachomatis DNA was detected in cervical or endometrial specimens taken more than three years before the salpingectomy, while it was detected in only $9 \%$ of the women (three of 33) whose specimens were taken within three years of the ectopic pregnancy (table 1). This may still underestimate the incidence of $C$ trachomatis in earlier specimens, since only a limited number of specimens taken more than three years before the ectopic pregnancy were available for testing. Nevertheless, the women with ectopic pregnancy investigated in this study were mostly in their early thirties, and the high incidence of $C$ trachomatis genital infection ( $31 \%)$ occurred while they were in their twenties. This $31 \%$ percent of women who had $C$ trachomatis in one or more genital specimens in the past is more than three times as high as the prevalence rate of $8-9 \%$ found in a large group of age adjusted asymptomatic women and pregnant women (Lan J et al, manuscript in preparation). Furthermore, the women investigated in this study may already have had tubal damage caused by $C$ trachomatis in their twenties, though it remained unnoticed for a long time because of postponed pregnancy. These data suggest that early $C$ trachomatis infection makes an important contribution to the later development of ectopic pregnancy, as generally accepted on the basis of the serological data. ${ }^{7-15}$ It is of particular interest that $C$ trachomatis positivity was found only in the endometrial biopsies (three of the four specimens) taken more than three years before salpingectomy (table 1). Although the study numbers are small, these data support the hypothesis that early $C$ trachomatis infections ascending to the upper genital tract (endometrium and fallopian tubes) play an important role in the pathogenesis of a substantial number of ectopic pregnancies.

In conclusion, this study showed that in the vast majority of ectopic pregnancies $C$ trachomatis was not present in the fallopian tubes at the time of the disease. However, the fact that a substantial number of women with ectopic pregnancy had cervical and endometrial $C$ trachomatis infections in the past indicates that ectopic pregnancy is in part the result of a previous episode of $C$ trachomatis infection, resulting in a scarred fallopian tube and subsequently leading to ectopic pregnancy.

This work was supported by a grant from the Prevention Fund of The Netherlands, No 281182 . The authors thank A-M de
Roda Husman and P J F Snijders for technical advice upon the processing of the cervical smears for PCR purposes, and C processing of the cervical smears
Burger for helpful discussions.

1 Beral V. An epidemiological study of recent trends in ectopic pregnancy. Br ₹ Obstet Gynaecol 1975;82:775-82.

2 Weström L, Bengtsson LP, Mårdh P-A. Incidence, trends, and risks of ectopic pregnancy in a population of women. $B M F$ 1981;282:15-18. 
3 Shiono PH, Harlap S, Pellegrin F. Ectopic pregnancies: rising incidence rates in northern california. Am 7 Public Health 1982;72:173-5.

4 Chow W-H, Daling JR, Cates W, Greenberg RS. Epidemiology of ectopic pregnancy. Epidemiol Rev 1987;9: 70-94.

5 Center for disease control. Ectopic pregnancy-United States 1981-1983. MMWR 1993;35:289-91.

6 Weström L. Effect of acute pelvic inflammatory disease on fertility. Am ₹ Obstet Gynecol 1975;121:707-13.

7 Sherman KJ, Daling JR, Stergachis A, Weiss NS, Foy HM, Wang SP, et al. Sexually transmitted diseases and tubal pregnancy. Sex Transm Dis 1990;17:115-21.

8 Svensson L, Mårdh P-A, Ahlgren M, Nordenskjöld. Ectopic pregnancy and antibodies to Chlamydia trachomatis. Fertil pregnancy and antibodic

9 Brunham RC, Binns B, McDowell J, Paraskevas M. Chlamydia trachomatis infection in women with ectopic pregnancy. Obstet Gynecol 1986;67:722-6.

10 Coste J, Job-Spira N, Fernandez H, Papiernik E, Spira A. Risk factors for ectopic pregnancy: a case-control study in France, with special focus on infectious factors. $A m \mathcal{F}$ Epidemiol 1991;133:839-49.

11 Chrysostomou M, Karafyllidi P, Papadimitriou D, Bassiotou V, Mayakos M. Serum antibodies to Chlamydia trachomatis in women with ectopic pregnancy, normal pregnancy or in women with ectopic pregnancy, normal pregnancy or
salpingitis. Eur f Obstet Gynecol Reprod Biol 1992;44:101-5.

12 Walters MD, Eddy CA, Gibbs RS, Schachter J, Hoden AE, Pauerstein C J. Antibodies to Chlamydia trachomatis and Pauerstein C J. Antibodies to Chlamydia trachomatis and
risk for tubal pregnancy. Am $\mathcal{F}$ Obstet Gynecol 1988;159: 942-6.

13 Coste J, Collet P, Laumon B, Job-Spira N, Brémond A. Sexually transmitted diseases as major causes of ectopic pregnancy: results from a large case-control in France. Fertil Steril 1994;62:289-95.

14 Kilström E, Lindgren R, Rydén. Antibodies to Chlamydia trachomatis in women with infertility, pelvic inflammatory disease and ectopic pregnancy. Eur f Obstet Gymecol Repmed Biol 1990;35:199-204.

15 Chow JM, Yonekura MY, Richwald GA, Grenland S, Sweet RL, Schachter J. The association between Chlamydia trachomatis and ectopic pregnancy. $\mathcal{F} A M A$ 1990;263:3164-7.
Gjønnaess H, Dalaker K, Ånestad G, Mårdh P-A, Kvile G, Bergan T. Pelvic inflammatory disease: etiologic studies with emphasis on chlamydial infection. Obstet Gynecol 1982;59:550-5.

17 Brunham RC, Binns B, Guijon F, Danforth D, Kosseim ML, Rand F, et al. Etiology and outcome of acute pelvic inflammatory disease. F Infect Dis 1988;158:510-17.

18 Mårdh P-A, Ripa T, Svensson L, Weström L. Chlamydia trachomatis infection in patients with acute salpingitis. $N$ Engl f Med 1977;296:1377-82.

19 Weström L, Wölner-Hanssen P. Pathogenesis of pelvic inflammatory disease. Genitourin Med 1993;69:9-17.

20 Brunham RC, Peeling R, Maclean I, Kosseim ML, Paraskevas M. Chlamydia trachomatis-associated ectopic pregnancy: serologic and histologic correlates. $\mathcal{F}$ Infect Dis nancy: serologic and

21 Diquelou J, Pia P, Tesquier L, Henry-Suchet J, Gicquel JM, Boyer S. La place de Chlamydia trachomatis dans l'étiologie infectieuse des grossessea extra-uterine. Gynecol Obstet Biol Reprod 1988;17:325-32

22 Hartford SL, Silva PD, diZerega GS, Yonekura ML. Ser- ologic evidence of prior chlamydial infection in patients with tubal ectopic pregnancy and contralateral tubal disease. Fertil Steril 1987;47:118-21.

23 Schachter J, Moncada J, Dawson CR, Scheppard J, Courtright $P$, Said ME, et al. Nonculture methods for diagnosing Chlamydial infection in patients with trachoma: a clue to the pathogenesis of the disease? F Infect Dis 1988;158: 1347-52.

24 Thejls H, Heimer G, Gnarpe J, Larsson G, Lundkvist Ö, Victor A. Diagnosis and prevalence of persistent chlamydia infection in infertile women: tissue culture, direct antigen infection in infertile women: tissue culture, direct antigen

25 Campell LA, Patton DL, Moore DE, Cappuccio AL, Mueller BA, Wang S-P. Detection of Chlamydia trachomatis ler BA, Wang S-P. Detection of Chlamydia trachomatis deoxyribonucleic acid

26 Gilroy CB, Thomas BJ, Taylor-Robinson D. Small numbers of Chlamydia trachomatis elementary bodies on slides detected by the polymerase chain reaction. $\mathcal{F}$ Clin Pathol 1992; 45:531-2.

27 Thompson CH, Rose BR, Cossart P. Detection of HPV DNA in archival specimens of cervical cancer using in situ hybridization and the polymerase chain reaction. $f$ Med Virol 1992;36:54-9.

28 Higuchi R. Rapid, efficient DNA extraction for PCR from cells and blood. Perkin Elmer Cetus Amplification 1990;2: 1-3.

29 Boom R, Sol CJA, Salimans MMM, Jansen CL, Wertheimvan Dillen PME, van der Noordaa J. Rapid and simple method for purification of nucleic acids. F Clin Microbiol 1990;28:495-503.

30 de Roda Husman AM, Snijders PJF, van den Brule AJC, Meijer CJLM, Walboomers JMM. Processing of long stored archival cervical smears for papilloma virus detection by the polymerase chain reaction. $\mathrm{Br} \mathcal{F}$ Cancer (in press).

31 Griffais R, Thibon M. Detection of Chlamydia trachomatis. Res Microbiol 1989;140:139-41.

32 Roosendaal R, Walboomers JMM, Veltman OR, Melgers I, Burger C, Bleker OP, et al. Comparison of different primer sets for detection of Chlamydia trachomatis by primer sets for detection of Chlamydia trachomatis by the polyme

33 Lan J, Walboomers JMM, Roosendaal R, van Doornum GJ, MacLaren DM, Meijer CJLM, et al. Direct detection and genotyping of Chlamydia trachomatis in cervical scrapes by using polymerase chain reaction and restriction fragment length polymorphism analysis. $\mathcal{f}$ Clin Microbiol 1993;31: 1060-5.

34 Tihie HTJ, Roosendaal R, Walboomers JMM, Theunissen JJH, Tjon Lim Sang RRM, Meijer CJLM, et al. Detection of Chlamydia pneumoniae using a general Chlamydia polymerase chain reaction with species differentiation after hybridization. $\mathcal{f}$ Microbiol Methods 1993;18:137-50.

35 An O, Radcliffe G, Vassallo R, Buxton D, O'Brien WJ, Pelletier DA, et al. Infection with a plasmid-free variant Chlamydia related to Chlamydia trachomatis identified by Chlamydia related to Chlamydia trachomatis identified by using multiple assays for nucl

36 Saiki RK, Scharf S, Faloona F, Mullis KB, Horn GT, Erlich $\mathrm{HA}$, et al. Enzymatic amplification of beta-globin genomic sequences and restriction site analysis for diagnosis for sickle cell anemia. Science 1985;230:1350-4. 